\title{
34. PRELIMINARY REPORT ON EARLY EOCENE CHEILOSTOME BRYOZOANS FROM SITE 308-LEG 32, DEEP SEA DRILLING PROJECT
}

\author{
Alan H. Cheetham, Department of Paleobiology, National Museum of Natural History, \\ Smithsonian Institution, Washington, D.C.
}

\section{INTRODUCTION}

Five samples of biogenous volcanic silt and sand of early Eocene age from Cores 1 to 3 at Site 308 on Koko Seamount (lat $34^{\circ} 58.94^{\prime} \mathrm{N}$, long $172^{\circ} 08.98^{\prime} \mathrm{E}$; water depth $1331 \mathrm{~m}$ ) yielded more than 700 specimens of Bryozoa (Table 1). Most of these specimens were recovered in foraminiferal and ostracode studies by H.P. Luterbacher (this volume); additional specimens were obtained from a bulk sample of about $50 \mathrm{cc}$ from Core 3.

Specimens from Core 1 are slightly better preserved than those from Cores 2 and 3 , which generally have a recrystallized appearance and encrustations of small iron sulfide crystals. Although most specimens are fragments of colonies less than $1 \mathrm{~cm}$ long, they show no obvious abrasion. A few of the encrusting colonies are still attached to substrates, and one erect colony has its basal attachment preserved (Plate 1, Figure 20). Distal ends of some fragmentary specimens preserve morphology characteristic of the growing extremities of colonies (Plate 2, Figure 2; Plate 3, Figure 3). The most fragmentary specimens are those in which the colony was jointed (species 4-8, Table 1) and particularly those in which internodes generally consist of just one or two zooecia (species 5-7). The nodes of these colonies consisted of organic material which would likely have decomposed soon after death.
About one-third of the specimens recovered are referable to the Order Cheilostomata, to which efforts at generic and specific identification are restricted in this report. At least 10 species of cheilostomes belonging to nine genera are represented in the five samples. Although more numerous in specimens, cyclostomes seem to be less diversified than the cheilostomes.

Most of the identifiable cheilostomes appear to belong to species and in some cases to genera that have not been previously described. This is not surprising, considering the scantiness of knowledge of Paleogene Bryozoa from the open Pacific. Moreover, even in regions from which the Paleogene record of cheilostomes has been extensively documented, such as the continental areas bordering the North Atlantic, knowledge of early Eocene faunas is less extensive than that of earlier and later Paleogene faunas. Study of Paleogene faunas which partly fill these gaps can be expected to contribute important new information to an understanding of cheilostome evolution and distribution.

Several of the apparently new cheilostome taxa are represented in the material from Site 308 by large numbers of specimens probably adequate for morphologic characterization. Others are represented by only a few fragmentary specimens. Until comparative studies of related taxa can be finished, the cheilostomes in this report are left, for the most part, in open nomenclature.

TABLE 1

Specimen Counts of Bryozoa Recovered from Site 308, Cores 1 to 3

\begin{tabular}{|c|c|c|c|c|c|}
\hline \multirow[b]{2}{*}{ Species of Cheilostomata } & \multicolumn{5}{|c|}{ Sample } \\
\hline & $1, \mathrm{CC}^{\mathrm{a}}$ & $2-2,10-12^{a}$ & $2, \mathrm{CC}^{\mathrm{a}}$ & $3, \mathrm{CC}^{\mathrm{a}}$ & $3, \mathrm{CC}^{\mathrm{b}}$ \\
\hline 1. Tubucella n. sp. 1 & 36 & 3 & 4 & 0 & 0 \\
\hline 2. $T$. n. sp. 2 & 36 & 0 & 0 & 36 & 22 \\
\hline$T$. n. sp. 1 or $T$. n. sp. 2 indet. & 5 & 0 & 0 & 0 & 0 \\
\hline 3. Smittinid n. gen.? n. sp. & 0 & 0 & 11 & 4 & 1 \\
\hline 4. Nellia aff. N. ventricosa (Canu) & 0 & 0 & 0 & 1 & 2 \\
\hline 5. Vittaticellid? n. gen. n. sp. & 0 & 0 & 0 & 0 & 23 \\
\hline 6. Scrupariid? gen. and sp. indet. & 0 & 0 & 0 & 0 & 14 \\
\hline 7. Epistomiid? gen. and sp. indet. & 0 & 0 & 0 & 0 & 7 \\
\hline 8. Poricellaria cf. P. limanowskii (Canu) & 0 & 0 & 0 & 0 & 3 \\
\hline 9. Cribrilaria radiata (Moll), s. 1 . & 0 & 0 & 0 & 0 & 2 \\
\hline 10. Antropora? sp. & 0 & 0 & 0 & 0 & 1 \\
\hline Total Cheilostomata & 77 & 3 & 15 & 41 & 75 \\
\hline Total Cyclostomatac & 260 & 3 & 21 & 250 & (d) \\
\hline Total Bryozoa & 337 & 6 & 36 & 291 & - \\
\hline
\end{tabular}

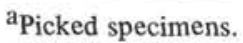

$\mathrm{b}_{\text {Bulk sample. }}$

${ }^{\mathrm{c}}$ Counts of cyclostomes approximate.

$\mathrm{d}_{\text {Not picked. }}$. 


\section{A. H. CHEETHAM}

Each species recognized, however, is illustrated, and descriptions of specimens, where adequate, are included. It is hoped that this new morphologic information is thus made available even though it has not been incorporated within formal new taxonomy.

I am indebted to Dr. H.P. Luterbacher for the material, to Miss JoAnn Sanner for technical assistance, and to Miss P.L. Cook, Mlle. M. Labracherie, and Dr. R. Lagaaij for reviewing the manuscript.

\section{DISCUSSION}

The apparent affinities of cheilostomes recovered from Cores 1 to 3 at Site 308 are consistent with an early Eocene age obtained from foraminiferal (Globorotalia formosa formosa) and nannoplankton (Discoaster lodoensis) evidence discussed elsewhere (Luterbacher, this volume). The overlapping parts of ranges of some of the cheilostome taxa are indicated in Figure 1.

The slight difference between the assemblages in Cores 1 and 2 on the one hand and Core 3 on the other
(Table 1) appears not to be significant. Tubucella $\mathrm{n} . \mathrm{sp} .1$ was found only in the upper cores, and Nellia aff. $N$. ventricosa was found only in the lowest one. (The restriction to Core 3 of species $4-10$ in Table 1 is of unknown significance because all were obtained from the bulk sample, all are represented by very small, not very wellpreserved specimens, and all except the vittaticellid? are rare.) The smittinid occurs in both groups of samples, but apparently has its "last occurrence" within Core 2 . The abundant occurrence of Tubucella n. sp. 2 in both the highest and lowest intervals sampled suggests that the apparent difference in assemblages is minor and within the limits of sampling variation.

More than half the cheilostome specimens recovered from the five samples belong to two species of Tubucella, both having rigidly erect, subcylindrical to bilaminate colonies. A third rigidly erect species (the smittinid) occurs with less frequency. Together with the majority of the cyclostome specimens, these species give a strong dominance of the rigidly erect colony form to these assemblages (Table 2). Encrusting specimens are few,

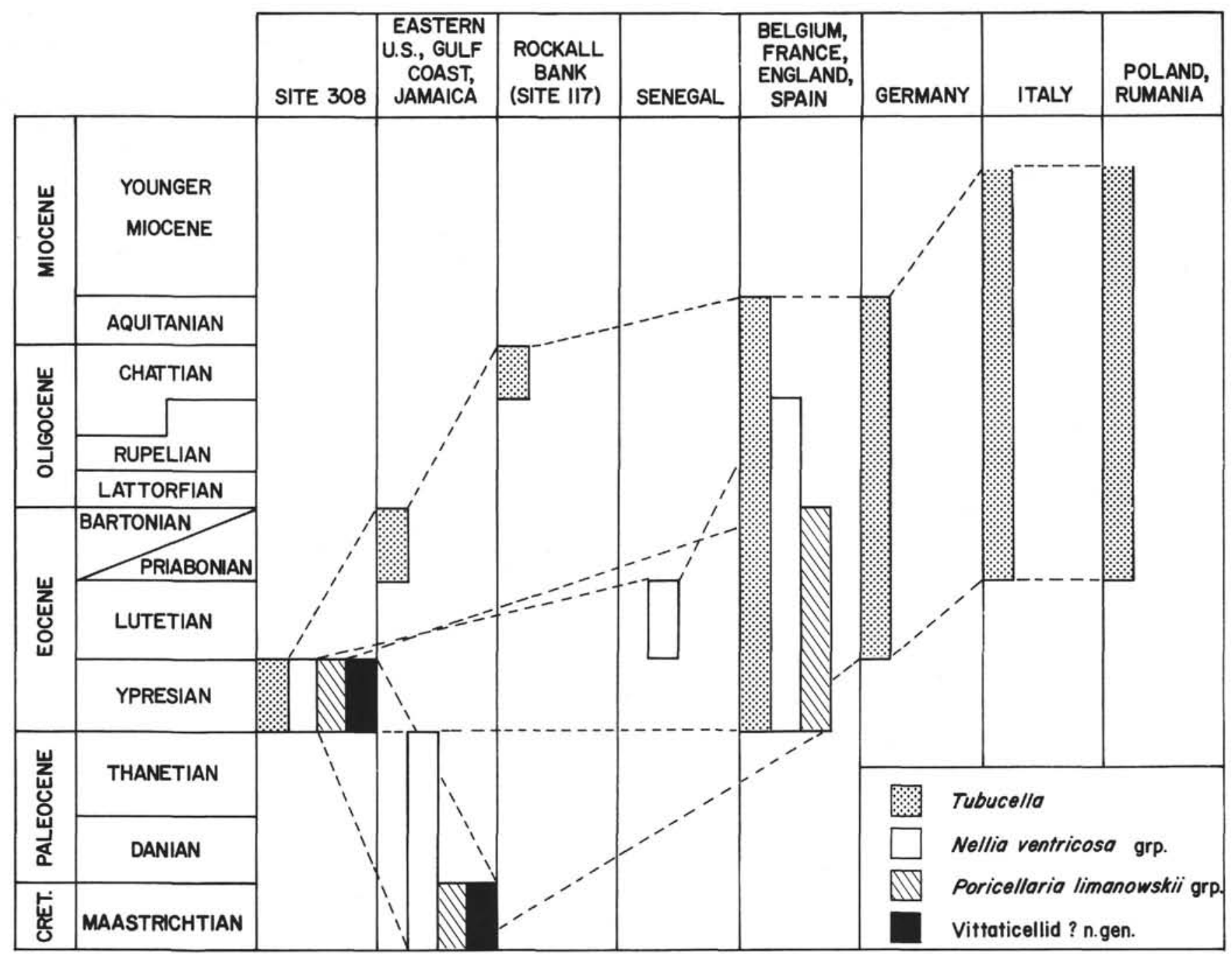

Figure 1. Ranges, shown by stages, of four groups of cheilostome taxa represented in lower Eocene samples from Site 308. Literature reports and unpublished data from which ranges were compiled are discussed in Systematic Descriptions. Ranges shown ignore nonoccurrences between oldest and youngest occurrences for each region. 
TABLE 2

Inferred Colony Forms of Specimens of Bryozoa

Recovered From Site 308, Cores 1 to 3

\begin{tabular}{lrrrrr}
\hline & \multicolumn{5}{c}{ Sample } \\
\cline { 2 - 6 } & $1, \mathrm{CC}^{\mathrm{a}}$ & $2-2,10-12^{\mathrm{a}}$ & $2, \mathrm{CC}^{\mathrm{a}}$ & $3, \mathrm{CC}^{\mathrm{a}}$ & $3, \mathrm{CC}^{\mathrm{b}}$ \\
\hline Cheilostomata & & & & & \\
$\quad$ Rigidly erect & 77 & 3 & 15 & 40 & 23 \\
$\quad$ Erect, jointed & 0 & 0 & 0 & 1 & 49 \\
$\quad$ Encrusting & 0 & 0 & 0 & 0 & 3 \\
$\begin{array}{c}\text { Cyclostomata } \\
\text { Rigidly erect }\end{array}$ & 200 & 3 & 6 & 200 & (d) \\
$\quad$ Encrusting & 60 & 0 & 15 & 50 & (d) \\
\hline
\end{tabular}

apicked specimens.

$\mathrm{b}_{\text {Bulk sample. }}$

${ }^{\mathrm{c} C}$ Counts of cyclostomes approximate.

$\mathrm{d}_{\text {Not picked. }}$

limited to Cribrilaria radiata, s. l., Antropora? sp., and some of the cyclostomes. Erect jointed species are limited to the cheilostomes. While these are very minor in total number of specimens, they are the dominant group in number of species, making up half of all of the cheilostome species recognized.

The bryozoan specimens from the five samples from Site 308 show remarkably few indications of the substrates upon which they grew. In the one bulk sample available for this study (308-3, CC), skeletal material suitable for attachment during at least early stages of colony growth includes abundant small benthonic foraminifers, ostracodes, and fragments of the bryozoans themselves, as well as rarer large octocoral spicules, echinoid spines, and shell fragments. Even with this range of apparently available substrates, only one bryozoan was found with evidence of attachment to shell (Plate 1, Figure 20), and a few were found on other bryozoans. None of the three encrusting cheilostomes and only 10 of the numerous encrusting cyclostomes (Table 2) were found with preserved substrates, although the configuration of basal walls of some cyclostomes suggests growth on shell. Encrusting cyclostomes were found on both cyclostomes and cheilostomes (both species of Tubucella). The encrusted cyclostomes are small, twiglike fragments adherent to the central parts of the much larger encrusting colonies. The encrusted Tubucella fragments are larger than the cyclostome colonies encrusting them, and some Tubucella specimens have traces of other epizoans, apparently poorly preserved calcareous worm tubes. Before encrustation, the membranous epifrontal layers of these encrusted specimens of Tubucella must have been removed to expose the calcareous frontal shield. The scarcity of epifauna on the abundant Tubucella fragments (4 of 43 specimens of $T$. n. sp. 1; 7 of 94 specimens of $T$. n. sp. 2) suggests that membranous layers may commonly have remained intact until, or nearly until, time of burial. The scarcity of preserved substrates among the encrusting bryozoans in general suggests that many of them may have encrusted perishable organic substrates or were loosely placed on the fine-grained sediment.
Bryozoan assemblages rich in Tubucella, Nellia ventricosa, and Poricellaria, along with some vittaticellids and many other genera of cheilostomes, are well known in Eocene deposits in France and other parts of Europe (see references cited in Table 3 ). Such assemblages have been interpreted as having lived at sublittoral depths (Labracherie, 1973), considerably shallower than the present 1331 meters water depth at Site 308. Cribrilaria radiata, s. 1., the only living "species" with which specimens recovered from Site 308 can be identified, has been reported from depths exceeding 1000 meters, although most of its reported occurrences are in much shallower water. The presence of Poricellaria seems particularly significant, because modern representatives of this genus are tropical, commonly reef-associated forms found only at depths less than 60 meters (Harmer, 1926; Lagaaij and Cook, 1973). The dominance of colonies with rigidly erect form in the samples from Site 308 argues for a depth not much less than the 60 meters maximum suggested by the presence of Poricellaria. It is also possible that Poricellaria and perhaps others of the forms with apparently jointed colonies represent either an epiplanktonic contribution or a bathymetrically displaced "reef" contribution to a benthonic assemblage that lived at sublittoral depths greater than 60 meters. However, there is no direct evidence for interpreting the assemblage as a mixture.

The geographic extension into the open Pacific of an Eocene cheilostome assemblage with such a "European" character provides new information for understanding cheilostome distributions. For example, the occurrence of Poricellaria in the lower Eocene at Site 308 is the first pre-middle Oligocene report of this genus from the Indo-West Pacific (Lagaaij and Cook, 1973) and suggests that it may have had circumtropical distribution very early in its known history. The occurrence of Tubucella at Site 308 extends the range of this genus for the first time into the Pacific. A similar cheilostome fauna from lower Eocene sediments at Site 246 in the Indian Ocean, but including many more species, is being studied by M. Labracherie (personal communication, 1974). 
TABLE 3

Previously Reported Occurrences of Species of Tubucella

\section{T. contorta (Canu, 1910)}

Lower Eocene, Aquitaine Basin, France (Labracherie, 1971)

T. mamillaris (Milne Edwards, 1836) [perhaps not all the same species; personal communication, M. Labracherie, 1974]

Middle-upper Eocene, Paris and Aquitaine Basins, France (d’Orbigny, 1850; Canu, 1908; 1910; 1918; 1925; 1931,

Dartevelle, 1935, Buge, 1946; Balavoine, 1949;1956a; 1956b

1957; 1960; Ducasse, Labracherie, and Vigneaux, 1961;

Ducasse, et al., 1964; Ducasse and Labracherie, 1967a;

1967b; Labracherie and Prud'homme, 1967; Labracherie, 1971)

Middle Eocene, Belgium (Canu and Bassler, 1929)

Upper Eocene, Spain (Ruiz de Gaona and Colom, 1950)

Upper Eocene, England (Cheetham, 1966)

Middle Oligocene-lower Miocene, France (Canu, 1906; 1907; $1910 ; 1918)$

Miocene, Rumania (Paghida, 1961)

T. aviculifera Canu and Bassler, 1929

Middle Eocene, Belgium (Dartevelle, 1933)

Middle Eocene, Aquitaine Basin, France (Ducasse, Labracherie, and Vigneaux, 1961; Ducasse, et al., 1963; Ducasse and Labracherie, 1967b; Labracherie and Prud'homme, 1967; Labracherie, 1971)

T. crenatula Canu and Bassler, 1929

Middle Eocene, Belgium (Dartevelle, 1933)

$T$. sp. 1 and $T$. sp. $2[=T$. aequalipartita; personal communication, M. Labracherie, 1974]

Middle-upper Eocene, Aquitaine Basin, France (Ducasse and Labracherie, 1967b)

T. aequalipartita Labracherie, 1971

Middle-upper Eocene, Aquitaine Basin, France

T. sp.

Middle Eocene-middle Oligocene, Aquitaine Basin, France (Labracherie and Prud'homme, 1967)

T. canui Labracherie, 1968

Upper Eocene, Aquitaine Basin, France

T. papillosa (Reuss, 1848)

Middle Eocene, Germany (Koschinsky, 1885)

Upper Eocene-Miocene, Italy (Reuss, 1869; Waters, 1891; Braga, $1963 ; 1965 ; 1968)$

Upper Eocene, Poland (Pazdro, 1929; Maecki, 1963)

T. gibbosa Canu and Bassler, 1920

Upper Eocene, South Carolina, Georgia, and Florida (Cheetham, 1963)

T. monilifera Canu and Bassler, 1917

Upper Eocene, North and South Carolina, Florida (Canu and Bassler, 1920; Cheetham, 1963)

$T$. cf. T. papillosa (Reuss, 1848)

Upper Oligocene, DSDP Site 117, Rockall Bank, North Atlantic (Cheetham and Håkansson, 1972)

\section{SYSTEMATIC DESCRIPTIONS}

\author{
Order CHEILOSTOMATA Busk \\ Suborder ANASCA Levinsen \\ Family SCRUPARIIDAE Busk, 1852 \\ Scrupariid? gen. and sp. indet. \\ (Plate 1, Figures 1-3)
}

A total of 14 zoarial fragments, all from Core 3, may represent a scrupariid, although they appear to be more heavily calcified than modern species in this family, which may apparently be entirely devoid of calcification (Harmer, 1926). Internodes consist of a single zooecium, begin with a simple opening at their proximal ends, and end with a single basomedian (as in Scruparia Oken, 1815) or a pair of basolateral (as in Brettia Dyster, 1858) articulating processes (Plate 1, Figures 2,3 ) at their distal ends. Walls appear thin and smooth except for small tubercles arranged in curving longitudinal rows on the tapered proximal cauda (Plate 1, Figure 2) The frontal membrane ap- parently occupied the distal half of the frontal surface, sloping obliquely to a terminal orifice. There is no apparent cryptocyst, although one specimen has a partial closure depressed slightly below the mural rim. Spine bases were not recognized, and ovicells were not found.

The zooecia are shaped less like those of uniserial species of Beania Johnston, 1840, in which the zooecia are also connected considerably differently.

A similar scrupariid?, probably congeneric with the one from Site 308, occurs in upper Eocene sediments at Carrière de l'Octroi, Blaye, France (personal communication, R. Lagaaij, 1974). The French specimens have longer proximal caudae, which are smooth.

Family ALDERINIDAE Canu and Bassler, 1927

Genus ANTROPORA Norman, 1903

\author{
Antropora? sp. \\ (Plate 1, Figure 4)
}

One small zoarial fragment from Core 3 is possibly referable to an undetermined species of Antropora. The apparently encrusting specimen, with completely calcified basal wall free of a preserved substrate, has a recrystallized appearance and is extensively coated with small iron sulfide crystals. Its preservation is insufficient to observe whether pore-chambers are present or whether the chambers of the few small interzooidal avicularia present reach the basal wall of the colony. The ovicell appears better developed than in the type-species of Antropora and seems to be completely immersed in the distal zooecium; its opening appears to have been fully dependent on the orifice of the maternal zooid.

\section{Family FARCIMINARIIDAE Busk, 1852 \\ Genus NELLIA Busk, 1852 \\ Nellia aff. N. ventricosa (Canu, 1914) (Plate 1, Figures 5, 6)}

Three zoarial fragments, all from Core 3, represent a species of Nellia similar to $N$. ventricosa, $N$. nellioides (Canu and Bassler, 1933), N. midwayanica Canu and Bassler, 1920, and an undescribed species from the upper Maestrichtian of Jamaica (Cheetham, 1968). The placement and orientation of avicularia on the proximal gymnocyst are most like $N$. ventricosa. Ovicells on the specimens from Site 308 are similar to those described by Labracherie $(1970)$ in $N$. ventricosa, except that they are more inflated and quadrate in distal outline and even less extensively covered by the gymnocyst of the distal zooecium. Ovicells have not been reported in $N$. nellioides, and no ovicells were recognized in the Jamaican species or in reexamination of the syntypes of $N$. midwayanica (USNM 63800,63801).

$N$. ventricosa has been reported from middle-upper Eocene in the Aquitaine Basin of France (Canu, 1914; Ducasse, Labracherie, and Vigneaux, 1961; Ducasse, et al., 1963; Labracherie and Prud'homme, 1967; Ducasse and Labracherie, 1967a; 1967b; Labracherie, 1970; 1971): from middle Eocene in Senegal (Gorodiski and Balavoine, 1962); and from upper Eocene in England (Cheetham, 1966). $N$. nellioides and $N$. midwayanica have been reported from Paleocene in the U.S., the former from New Jersey (Canu and Bassler, 1933) and the latter from Georgia, Alabama, and Arkansas (Canu and Bassler, 1920).

\section{Family PORICELLARIIDAE Harmer, 1926 Genus PORICELLARIA D'Orbigny, 1854 \\ Poricellaria ef. P. limanowskii (Canu, 1907) (Plate 1, Figures 7, 8)}

Three zoarial fragments, all from Core 3 , appear to be conspecific with specimens from the lower Eocene of France given this tentative designation (Cheetham, 1973). The specimens from Site 308 are small parts of internodes with a recrystallized appearance and include only two nearly complete zooecia. Even so, two or three measurements for each of the 11 variates used to infer evolutionary trends in poricellariid morphology (Cheetham, 1973) could be obtained from frontal zooecia. To estimate the position of the specimens from Site 308 relative to the zooecial morphology of Cretaceous to Recent evolutionary lineages, their means for each of the 11 variates were transformed to the same set of principal components (Figure 2). With respect to the four morphologic properties represented by the principal components, the specimens from Site 308 fit within the range of variation of an early 


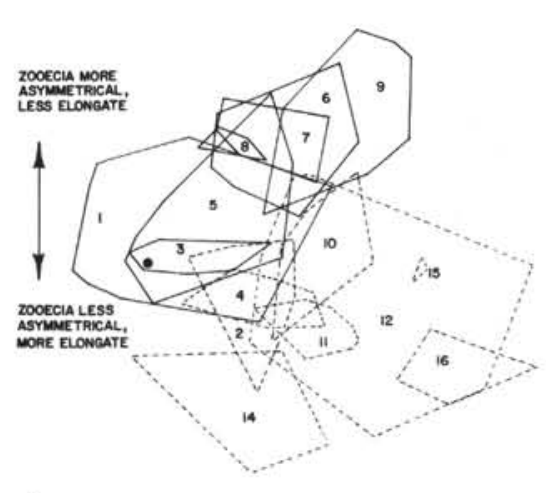

A

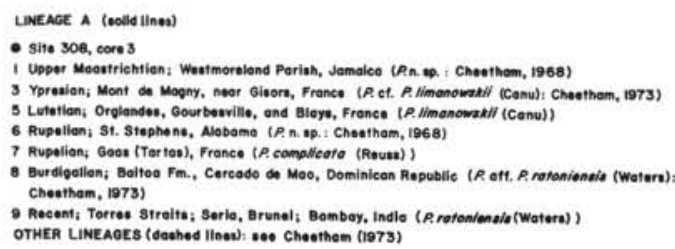

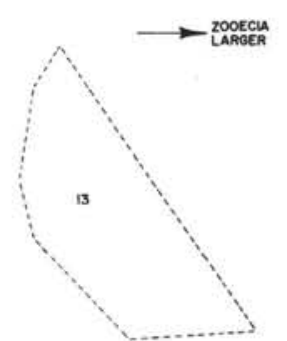

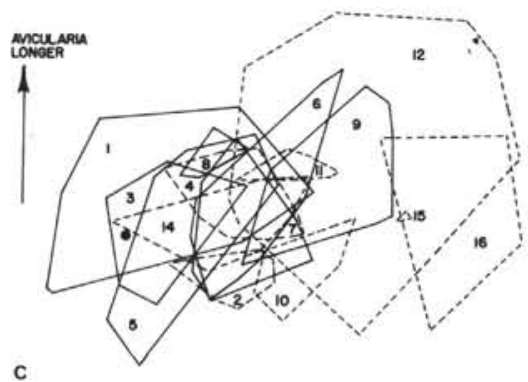

B
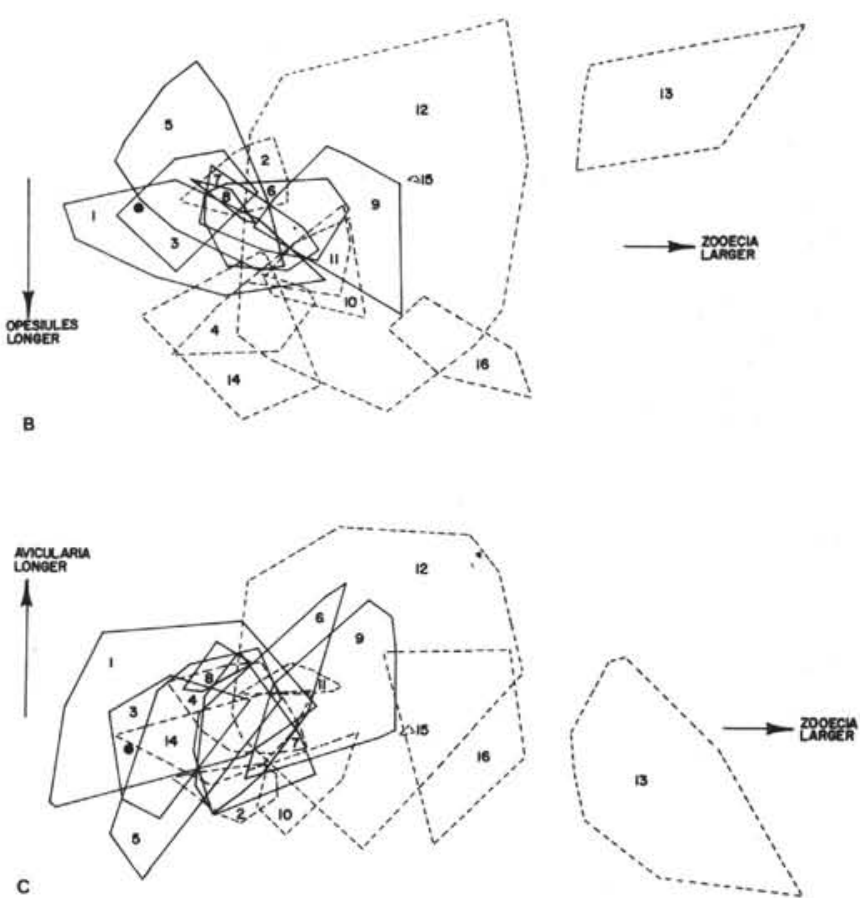

Figure 2. Comparison of Poricellaria from lower Eocene sample from Site 308 with Cretaceous-Recent poricellariids studied by Cheetham (1973). A-C are based on principal components analysis of 11 measured variates on 16 samples; the horizontal axis in each plot is the first principal component; the vertical axes are the second, third, and fourth principal components, respectively, in $A, B$, and $C$. Polygons are ranges of variation of frontal zooecia within each sample, and the black dot shows the mean morphologic position, relative to these samples, of frontal zooecia in Poricellaria from Site 308.

group of poricellariids, leading from $P$. n. sp. from the upper Maestrichtian of Jamaica to $P$. limanowskii from the middle Eocene of France. The Jamaican specimens are unique among poricellariids in their possession of paired avicularia (Cheetham, 1968), and thus differ significantly from the specimens from Site 308 . The best fit, then, seems to be with $P$. cf. $P$. limanowskii, but the fragmentary evidence from Site 308 based only on frontal zooecia has not provided an adequate estimate of variation on which to base a confident specific assignment.

\section{Family EPISTOMIIDAE Gregory, 1903 \\ Epistomiid? gen. and sp. indet. (Plate 1, Figures 9, 10)}

Seven small zoarial fragments, all from Core 3, seem to have structure resembling that of epistomiid internodes, although their preservation is too coarse to show sufficient morphologic detail for a close comparison with modern species of Epistomia Fleming, 1828, or Synnotum Pieper, 1881. The proximal and distal articulating ends of each internode have four openings each. The proximal openings appear to be the proximal ends of expanded (distal) portions of a pair of zooecia and the narrow, tubular (middle?) portions of another pair. The distal openings appear to be the distal ends of the presumed middle portions and the proximal ends of a new pair. Protuberant structures, possibly remnants of avicularia (Plate 1, Figure 9), occur near midlength on the frontal sides of internodes, but it is not clear to which portions of zooecia they are attached.

Fossil epistomiids are known from occurrences of Synnotum in rocks as old as lower Miocene (Lagaaij, 1968), and from specimens similar to those from Site 308 in the lower Eocene of Horsarrieu (Landes), France (personal communication, R. Lagaaij, 1974).

\section{Suborder ACANTHOSTEGA Levinsen \\ Family CRIBRILINIDAE Hincks, 1879 \\ Genus CRIBRILARIA Canu and Bassler, 1928 \\ Cribrilaria radiata (Moll, 1803), sensu lato (Plate 1, Figures 11, 12)}

Two small zoarial fragments, both from Core 3 , are referable to this morphologically variable, long-ranged complex reported from Paleo- cene (Cheetham and Hakansson, 1972) to Recent and from many parts of the world. The specimens from Site 308 are too coarsely preserved to show morphologic details of the kind used by Harmelin (1970) to distinguish among living Mediterranean species of Cribrilaria. Compared to $C$. radiata, sensu stricto, as described by Harmelin, costae are fewer (15-17 per zooecium) and oral spines are more numerous (5-8 per zooecium) in the specimens from Site 308. Although an interzooidal avicularium is present on one specimen (Plate 1, Figure 11), the details of its structure are obscure.

\section{Suborder ASCOPHORA Levinsen Family VITTATICELLIDAE Harmer, 1957 \\ Vittaticellid? n. gen.}

The genus Vittaticella Maplestone, 1901, characterized by vittate zooecia arranged for the most part in mono- and dizooecial internodes, is the most widespread member of a family of morphologically highly specialized ascophorans. Fossils as old as middle Eocene have been assigned to this genus (Lagaaij and Cook, 1973). Living species can have, in addition to mono- and dizooecial internodes, ovicelled zooids arranged in uniserial, polyzooecial internodes.

In the genus Ditaxipora MacGillivray, 1895, also assigned to the Vittaticellidae, internodes are biserially polyzooecial, including both ovicelled and nonovicelled zooecia, which are also vittate. Fossils as old as middle Eocene have been assigned to this genus (Labracherie, 1971).

Other vittate, biserially polyzooecial species are known from deposits as old as Paleocene (Cheetham and Hakansson, 1972). These presumed vittaticellids are somewhat similar to middle Eocene to Oligocene species of the genera Ditaxiporina Stach, 1935, and Caberoides Canu, 1908, both of which have nonvittate zooecia and have been referred to the Family Ditaxiporinidae Cheetham, 1966. Waters (1891) described the upper Eocene type-species of Ditaxiporina, D. septentrionalis, to have two types of internodes: mono- and dizooecial ones similar to those of Vittaticella; and biserially polyzooecial ones, including both ovicelled and nonovicelled zooecia, similar to those of Ditaxipora. Stach (1935) suggested that the internodes containing only a few zooecia "...probably represent the first few zooecia in the development of a long internode." The articulating processes on mono- and dizooecial internodes illustrated by Waters 
(1891, pl. 1, fig. 1, 2, and 6), however, do not seem consistent with this interpretation, and the possibility that the two types of internodes are present in the same species and also in two different families cannot be rejected.

The species from Site 308 described below is represented predominantly by mono- and dizooecial internodes, but one fragment appears to be part of a biserial internode. The details of zooecial morphology in this species furthermore are similar to those in an undescribed upper Maestrichtian species from Jamaica (sample listed in Cheetham, 1968) which includes distinctive, biserial, ovicell-bearing polyzooecial internodes in addition to mono- and dizooecial ones. The similarities between the Jamaican species and that from Site 308 strongly suggest that the two are congeneric. Both species have zooecia lacking either vittae characteristic of Vittaticellidae or the scattered frontal perforations characteristic of Ditaxiporina. Their generic and even familial assignment is therefore open to question. Although preservation of both the Jamaican material and that from Site 308 is inadequate for observation of the details of structure of the frontal shield, this structure appears to be similar to that in cribrimorphs, but which is also presumably present in some vittaticellids such as Costaticella Maplestone, 1899. These two species are then very tentatively given the awkward designation of "vittaticellid? n. gen."

\section{Vittaticellid? n. gen. n. sp.}

(Plate 1, Figures 13-17)

A total of 23 zoarial fragments, all from Core 3 are referred to this species, which is distinguished from its Jamaican upper Maestrichtian congener in having the distolateral avicularia directed more laterally and with their palatal surfaces facing basolaterally rather than frontally.

Zoarial fragments include 20 monozooecial and two dizooecial internodes and one small fragment of a biserial, presumably polyzooecial internode (Plate 1, Figure 17). Most specimens have broken frontal shields and proximal tips. Some monozooecial internodes (Plate 1, Figures 13, 14) have frontal shields and proximal tips preserved.

As in the Jamaican species, zooecia are strongly bulbous, tapered both proximally and distally. On the basodistal side of the distal end of the zooecium is an articulating process of about the same diameter as the tapered proximal ends of apparently unbroken monozoecial internodes. Within a smooth proximal and lateral portion continuous with lateral and basal walls, the frontal shield includes a finely transversely ribbed sternal area (Plate 1, Figures 13, 14). Specimens are too coarsely preserved to determine whether ribs are hollow costae with intervening lacunae. The immediately suboral rib is thicker than the others and with its median portion projecting slightly over the proximal lip of the orifice as a mucro. The orifice is subterminal on the frontal shield, semicircular in outline, and flanked by two pairs of distolateral protuberances (spines?), these latter features lacking in the Jamaican species. Paired distolateral avicularia (broken on some specimens) project obliquely outward and distally from just below the level of the orifice. The palatal surface faces laterally and slightly basally and is thus hidden in frontal view. The rostrum is poorly preserved, and no crossbar was observed. Ovicells were not found in this species, but in the Jamaican species are borne by all zooecia in a biserially polyzooecial internode, lie prominently on the distal zooecium, and bear a few large scattered frontal perforations.

$$
\begin{aligned}
& \text { Measurements }(\mathrm{mm}) ; n=4 \\
& \text { ho: } x=0.069 ; s=0.0106 \\
& \text { lo: } x=0.074 ; s=0.0080 \\
& \text { length sternal area: } x=0.183 ; s=0.0302 \\
& \text { width sternal area: } x=0.097 ; s=0.0222 \\
& \text { Lav: } x=0.076 ; s=0.0119
\end{aligned}
$$

\section{Family SMITTINIDAE Levinsen, 1909}

\section{Smittinid n. gen. ?}

The species described below under this tentative and admittedly awkward designation shows similarities in zooecial morphology to fossil and modern species referred to smittinid genera such as Smittoidea Osburn, 1952, and Hemismittoidea Soule and Soule, 1973. Particularly striking are similarities in the frontal shield, primary orifice, ovicells, and median suboral avicularium with Smittoidea variabilis (Canu, 1908) from the middle-upper Eocene of Europe. The morphology of the zoarium of the species from Site 308 is unlike that in most smittinids, variable though these are, but seems to parallel that in living species such as Smittina exclusa Harmer, 1957, and $S$. aviculata (Calvet, 1906) $(=S$. avicularia [Calvet]: Calvet, 1931). In both of these species and that from Site 308 zooidal orifices are restricted to one side of the narrow erect branches. In describing $S$. exclusa, Harmer (1957) called attention to the similarity between the basal sides of its unilaminate branches and those of the Family Sertellidae Jullien, 1903, on which thick, presumably extrazooidal calcareous deposits with irregular cuticular partitions ("vibices") are present. However, Harmer did not place $S$. exclusa in the Sertellidae because it differs in zooecial characters, particularly in the peristome and ovicells. $S$. aviculata apparently lacks such basal deposits, the basal sides of its branches being composed of the walls of the marginal zooids separated by regular intercalary cuticles (Calvet, 1931). The species from Site 308 appears to have the same zoarial morphology as $S$. exclusa, but evaluation of the possible generic significance of this morphology must await restudy of some of the multitude of fossil smittinids described from Europe and North America.

\section{Smittinid n. gen. ? n. sp.}

(Plate 1, Figures 18-22)

A total of 16 zoarial fragments from Cores 2 and 3 are referred to this species which differs from Smittina exclusa Harmer, 1957, in lacking peristomes and oral spines, in the form and position of the suboral avicularium, in lacking additional avicularia on the frontal and basal surfaces, and in having less immersed ovicells. From Smittoidea variabilis (Canu, 1908), it differs in colony form, particularly in having calcareous deposits (presumably extrazooidal) on the basal sides of branches; in lacking oral condyles and peristomes; in the degree of perforation of ovicells; and in the shape and orientation of the suboral avicularium.

Zoarial fragments are unilaminate, elliptical in cross section, narrow, and subequally branched. The basal attachment (Plate 1, Figure 20, ) consists of a pad of calcareous material similar to that on the basal sides of branches. Branches consist of two to four longitudinal rows of zooecia, the number increasing to a point of branching (Plate 1, Figure 22). The frontal side of a branch is moderately curved transversely so that zooecia in opposite marginal rows of a 3or 4-serial branch open at almost right angles to each other. The basal side of a branch is moderately curved to flattened, consisting of one or two series of irregularly polygonal sectors (Plate 1, Figures 20,21) separated by distinct lines in a zigzag pattern apparently marking the position of cuticular partitions. Sector lines do not correspond to zooecial boundaries and in some cases are more than one zooecial length apart. Each sector has one or more centrally to marginally placed pores communicating with adjacent zooecia through their floors. Avicularia, such as reported on basal sides of Smittina exclusa, were not observed.

Zooecia in adjacent longitudinal series alternate in position and are separated by distinct, presumably cuticular lines in all specimens observed. Similar lines separate marginal zooecia from the calcareous material on the basal sides of the branches. In frontal view, zooecia are irregularly rectangular to hexagonal.

The calcified frontal shield is thin and smooth in all specimens observed, whether apparently near a growing margin (Plate 1, Figure 18 ), or others. Perforations are few and restricted to the margins, the most prominent being a proximal pair, sometimes single or absent. Additional lateral perforations or bilateral pairs may be present between the proximal pair and the orifice.

The orifice is large, semicircular, and subterminal on the frontal surface. A broad, but rudimentary median proximal denticle is covered by the avicularium in all but a few zooecia (Plate 1, Figures 18, 22). Condyles and oral spines were not observed.

A median suboral avicularium is present on most zooecia, apparently having developed unilaterally from a marginal perforation (Plate 1, Figure 18) as in Hemismittoidea (see Soule and Soule, 1973). The fully developed avicularian chamber is swollen and hides the proximal lip of the orifice from frontal view. The strongly elevated rostrum is directed obliquely proximally and frontally, toward the center of the branch on zooecia in marginal rows, and either toward or away from the center of a branch on those in central rows.

The rostral palate is nearly perpendicular to the frontal surface, facing the orifice, elongate-triangular in shape, with a blunt or rounded tip. A complete crossbar, commonly broken, is placed near the broadly rounded antirostral end.

Ovicells were observed in only two specimens (Plate 1, Figure 19), confined to zooecia of central rows. The ovicell is subimmersed in the 
distal zooecium, the enlarged proximal frontal perforations of which lie distal to the ovicell margin. The frontal side of the ovicell appears to consist of a single calcified lamina, smooth except for a crescentic row of small perforations at about its midlength. The frontal shields of distally and laterally adjacent zooecia encroached upon the ovicell surface, covering it as far proximally as the row of perforations. The contribution from the frontal shield of each zooecium is separated from the others by a presumed cuticular line. The arched opening of the ovicell appears to have been above the level of the operculum of the maternal zooecium and therefore to have been only semidependent.

Ovicelled zooecia are significantly longer and have significantly wider orifices than nonovicelled zooecia ( 0.05 level, t-test); differences in width of zooecium, length of orifice, and length of avicularium are not significant.

Measurements (mm)

Nonovicelled zooeciea; $n=10$

Lz: $x=0.454 ; s=0.0453$

lz: $x=0.269 ; s=0.0363$

ho: $x=0.137 ; s=0.0097$

lo: $x=0.144 ; s=0.0115$

Lav: $x=0.128 ; s=0.0124$

Ovicelled zooecia; $n=3$

Lz: $x=0.535 ; s=0.0841$

Iz: $x=0.302 ; s=0.0084$

ho: $x=0.143 ; s=0.0168$

lo: $x=0.160 ; s=0.0084$

Lav: $x=0.134 ; s=0.0168$

Lov: $x=0.185 ; s=0.0084$

lov: $x=0.207 ; s=0.0049$

The ovicells of the holotype of Smittina exclusa (Siboga 168.F, 1441,6, p. $\left.133^{1}\right)$ are less fully immersed than is apparent in Harmer's illustration (1957, pl. 63, fig. 15). A central part of the ovicell roof is bare of frontal overgrowths from adjoining zooids, and its surface bears numerous minute pores similar to those in the specimens from Site 308 .

\section{Family MARGARETTIDAE Harmer, 1957}

\section{Genus TUBUCELLA Canu and Bassler, 1917}

Both species from Site 308 that are referred to Tubucella have numerous, well-developed adventitious avicularia and in this respect apparently differ from the type-species of Tubucella, T. mamillaris (Milne Edwards, 1836). Avicularia have been reported, however, in many other species of this genus. These avicularia-bearing species are much like $T$. mamillaris in other characters, and, moreover, their avicularia vary considerably in position, orientation, size, and frequency of occurrence. The paucity of avicularia in some species, such as $T$. papillosa (Reuss, 1848) and T. gibbosa Canu and Bassler, 1920, suggests that their apparent absence in $T$. mamillaris may have little taxonomic significance.

The reported occurrences of species of Tubucella, in deposits ranging from lower Eocene to Miocene, are summarized in Table 3.

Tubucella n. sp. 1

(Plate 2, Figures 1-6; Plate 3, Figures 3-5)

A total of 43 fragments of zoaria, all from Cores 1 and 2, belong to an apparently undescribed species of Tubucella seemingly distinguished by prevalent, generally single, relatively large, elliptical, median suboral avicularia.

Zoarial fragments are subcylindrical to bilaminate, all seemingly representing an erect, branching colony form. Subcylindrical specimens have as few as six rows of zooecia, and bilaminate specimens generally widen distally to as many as 10 rows of zooecia on each face. Attachment bases were not recognized. Two or three specimens with thinly calcified walls at their distal extremities appear to preserve features of zooecia near the growing margins of the colony (Plate 2, Figure 2; Plate 3, Figure 3), although the growing extremities themselves appear to have been broken off.

Zooecia are arranged in longitudinal rows, those in adjacent rows alternating in position. Distinct lines separating zooecia longitudinally at all stages of calcification apparently mark positions of intercalary cuticles, although there is only a slight tendency for zooecia to have separated along these lines in the fragmentation of zoaria. In frontal view, zooecia have the elongate shape characteristic of the genus, but division of the frontal surface into a proximal, ascopore-bearing region and a distal, peristomial region is less definite than in $T$. mamillaris or in $T$. n. sp. 2 described below.
The calcified shield bearing the primary orifice and ascopore is frontally inflated, even in heavily calcified zooecia, and bears a few evenly spaced, quincuncially arranged perforations. The ascopore, markedly larger than the frontal perforations, lies about halfway between the primary orifice and the proximal margin of the zooecium. In thinly calcified zooecia (Plate 2, Figure 2; Plate 3, Figure 3), the ascopore is distinctly rimmed and lies at the highest point on the frontal surface. In more heavily calcified zooecia (Plate 2, Figures 1,3 ), the ascopore lies in a craterlike depression. Frontal perforations extending around the distal margin of the ascopore, are more widely spaced than those on the more proximal part of the frontal shield; the space between the ascopore and the primary orifice is slightly depressed in the least calcified zooecia or generally covered by an avicularium in heavily calcified ones.

The peristome is a distal continuation of the frontal shield and is sessile throughout its length, but with the proximal lip of the secondary orifice rising above the frontal surface in more heavily calcified zooecia. Frontal perforations are commonly limited to the lateral margins of the peristome, but on some zooecia, especially ovicelled ones, a row of perforations continues around the distal margin of the secondary orifice. The secondary orifice is subcircular and in some of the more heavily calcified zooecia is closed completely by a smooth calcareous lamina (Plate 2, Figure 3). In such zooecia, the ascopore, frontal perforations, and, where present, avicularia remain unobstructed.

The primary orifice is hidden from frontal view by the peristome in all but the most thinly calcified distal zooecia (Plate 2, Figure 2). Semicircular in shape, it is inclined steeply distally downward from the frontal surface, rather than nearly paralleling it as does the secondary orifice.

Avicularia are more consistently present in this species, and in $T . \mathrm{n}$. sp. 2 described below, than reported in previously described species of Tubucella. Even so, zooecia lacking avicularia occur sporadically and seemingly at random positions in many specimens, including those in which zooecia are quite heavily calcified and presumably at advanced stages of ontogeny (Plate 2, Figure 6). Although the avicularia all appear adventitious and associated with the peristome, there is considerable variation in their position, orientation, and size. Most commonly, a median suboral avicularium extends from the proximal lip of the secondary orifice nearly to the ascopore, from which it is commonly separated by a few frontal perforations. This type of avicularium, present on both ovicelled and nonovicelled zooecia, was apparently developed bilaterally from a pair of perforations margining the peristome (Plate 2, Figure 2), although its sometimes more lateral position (Plate 2, Figure 1) suggests an occasional unilateral origin. The elevated rostrum of this type of avicularium is generally directed proximally, either longitudinally or slightly obliquely. On some zooecia, the median suboral avicularium is reversed in orientation, the elevated rostrum then directed distally, either longitudinally or slightly obliquely, to a position just short of the secondary orifice (Plate 2, Figure 6). Avicularia with distally directed rostra are significantly more variable in length than those with proximally directed rostra ( 0.05 level, F-test). Additional smaller avicularia are present on the peristomes of a few zooecia. On some ovicelled zooecia, a distolateral avicularium apparently developed from a marginal perforation (Plate 3, Figure 4); its rostrum is directed medially to distomedially. On a very few zooecia on a subcylindrical specimen, a small avicularium flanks the median suboral one laterally (Plate 2, Figure 5). Avicularia of all kinds are elliptical in palatal outline and, except where broken, are furnished near their antirostral ends with a simple, complete crossbar.

Only a few specimens bearing ovicells were found (Plate 3, Figures 4,5 ). In these, the ovicelled zooecia are confined to a variable number of central longitudinal rows of each zoarial face, with two or three rows of nonvicelled zooecia lateral to them. Nonovicelled zooecia were also observed to follow ovicelled ones distally in one specimen (Plate 3, Figure 4). Ovicelled zooecia are distinguished principally by the distal inflation of the frontal outlines of their peristomes and by the upward and backward flexure of the distal portion of the peristome over the primary orifice to form a peristomial chamber between the primary and secondary orifices. A crown of frontal perforations slightly larger than the more proximal ones completely margins the ovicell distally, with an additional avicularium commonly placed in the crown. Ovicelled zooecia are significantly wider and have significantly larger secondary orifices than nonovicelled zooecia $(0.05$ level, t-test). They do not differ significantly in length.

Measurements $(\mathrm{mm})$

Nonovicelled zooecia: $n=10$ 


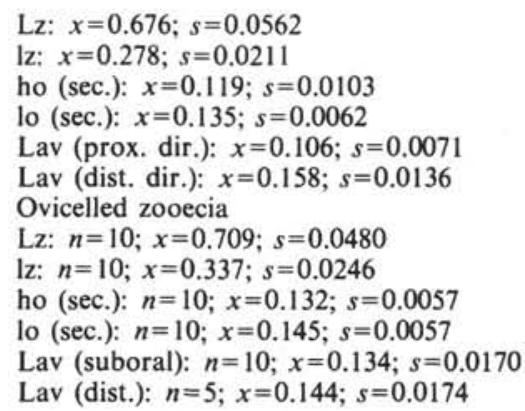

Tubucella n. sp. 2

(Plate 3, Figures 1, 2; Plate 4, Figures 1-5)

A total of 94 fragments of zoaria, all from Cores 1 and 3, belong to a second apparently undescribed species of Tubucella. This species seems to be distinguished by its prevalent, commonly paired, relatively small, elliptical, lateral oral avicularia. Its avicularia are highly significantly smaller than all types of avicularia measured in $T$. n. sp. 1 (0.01 level, t-test).

Zoarial fragments are subcylindrical to bilaminate, apparently representing the same colony form as in $T$. n. sp. 1. Neither attachment bases nor growing margins were recognized.

Zooecia are arranged as in $T$. n. sp. 1, separated longitudinally by apparent cuticular lines at early stages of calcification (Plate 3, Figure 2 ). The elongate frontal outlines characteristic of zooecia in this genus are readily apparent at this stage, and the frontal surface is distinctly divided into a proximal, ascopore-bearing region and a distal, peristomial region by a distinct transverse presumably cuticular line as in $T$. mamillaris and in contrast to $T . \mathrm{n}$. sp. 1 . At later stages of calcification (Plate 4, Figures 1-4), zooecial boundaries appear disrupted so that the frontal surface of the branch is divided by presumed cuticular lines into sectors no longer corresponding to longitudinal zooecial rows. This pattern is commonly accompanied by closure of secondary orifices and in some cases by closure of avicularia (Plate 4, Figures 1, 4).

The calcified frontal shield is frontally inflated and bears numerous, evenly spaced, quincuncially arranged perforations. The ascopore, only slightly larger than the frontal perforations, lies near the peristomial suture, without differentiation of the frontal surface in its vicinity.

The peristome is sessile like that of $T$. n. sp. 1 for most of its length, but commonly has a free portion bearing the secondary orifice; the free peristome is especially pronounced in zooecia with ovicells (Plate 3 , Figure 1). Lateral and distal perforations are supplemented by more medial pits and longitudinal grooves, giving the peristome a corrugated appearance as in $T$. mamillaris. The secondary orifice is subcircular, and in a few zooecia is closed by a lamina similar to that in $T$. n. sp. 1, except that the accompanying avicularia can also be closed (Plate 4, Figure 4).

The primary orifice is hidden from frontal view in all specimens by the long peristome. Its shape and orientation are like those in $T$. n. sp. 1.

Avicularia appear to be present on nearly every zooecium, although, because of their small size, they are not easily distinguishable from frontal perforations if their crossbars have been broken. Like those of $T$. n. sp. 1, the avicularia are associated with the peristome, but are lateral to the secondary orifice rather than suboral, and show less variation in size, position, and orientation. Most commonly, avicularia are distolateral to the secondary orifice and either single or paired (Plate 3, Figure 2; Plate 4, Figure 5). Presumably, each is derived from a single marginal perforation. The rostrum is slightly elevated and directed proximally and slightly inward or outward. On some specimens, avicularia are proximolateral to the secondary orifice, and where unpaired, can be similar in appearance to some of those in $T$. n. sp. 1, although not in a median suboral position. On ovicelled zooecia (Plate 3, Figure 1), avicularia are at the distolateral margin of the peristome which, because of the backward flexure over the ovicell chamber, is removed from the secondary orifice. Avicularia are all elliptical in palatal outline and, except where presumably broken, are furnished with crossbars similar in form and position to those in $T . \mathrm{n}$. sp. 1 .

Only one specimen bearing ovicells was found, the ovicelled zooecia being confined to the central longitudinal rows on each face (Plate 3 ,
Figure 1), similar to those in $T$. n. sp. 1. The peristomes of ovicelled zooecia are highly inflated in their frontal outlines, and the backward and upward flexure over the primary orifice forms an extensive distal cover to the peristomial chamber. This is margined by a row of large frontal perforations among which are one or two distolateral avicularia. No consistent differences in dimensions were found between ovicelled and nonovicelled zooecia.

Measurements (mm)

Nonovicelled zooecia; $n=10$

Lz: $x=0.834 ; s=0.1394$

Iz: $x=0.285 ; s=0.0457$

ho (sec.): $x=0.113 ; s=0.0099$

lo (sec.): $x=0.120 ; s=0.0168$

Lav: $x=0.071 ; s=0.0082$

Ovicelled zooecial

Lz: $n=4 ; x=0.792 ; s=0.0186$

lz: $n=5 ; x=0.306 ; s=0.0282$

ho (sec.): $n=6 ; x=0.084 ; s=0$

lo (sec.): $n=7 ; x=0.105 ; s=0.0088$

Lav: $n=7 ; x=0.078 ; s=0.0105$

\section{REFERENCES}

Balavoine, P., 1949. Note sur la faune lutétienne de Villers-surRoule et de Venables (Eure): Mus. Nat. Hist. Nat., Paris Bull., v. 21, p. 772-775.

, 1956a. Le gisement fossilifere de Saint-Gervais (Seine-et-Oise): Mus. Nat. Hist. Nat., Paris Bull., v. 28, p. 419-427.

1956b. Quelques Bryozoaires éocènes du bassin de Paris et du Cotentin de la collection Gustave-F. Dollfuss: Mus. Nat. Hist. Nat., Paris Bull., v. 28, p. 319-325.

1957. Nouveaux gisements de Bryozoaires dans le lutétien du bassin de Paris: Mus. Nat. Hist. Nat., Paris Bull., v. 29, p. 190-192.

1960. Bryozoaires du lutétien de Bois-Gouèt (LoireAtlantique): Soc. Géol. France Bull., ser. 7, v. 1, p. 245-251. Braga, G., 1963. I Briozoi del Terziario veneto: Soc. Paleontol. Ital. Boll., ser. 2, v. 1, p. 16-55.

1965. Briozoi dell' Oligocene di Possagno (Trevigiano Occidentale): Soc. Paleontol. Ital. Boll., ser. 2, v. 4 , p. $216-244$.

1968. Notizie preliminari su una fauna a Briozoi del Miocene inferiore del Trevigiano Occidentale. In Committee on Mediterranean Neogene Stratigraphy, Proc. IV Session, Bologna, 1967: Gior. Geol., v. 35, p. 95-106.

Buge, E., 1946. Catalogue des Bryozoaires types et figurés de la collection du Laboratoire de Paléontologie du Muséum National d'Histoire Naturelle, part 4, Bryozoaires cheilostomes de l'éocène du bassin de Paris figurés par F. Canu (1907-1910): Mus. Nat. Hist. Nat., Paris Bull., v. 18, p. 428439.

Calvet, L., 1931. Bryozoaires provenant des campagnes scientifiques du Prince Albert I de Monaco: Res. Campagnes Sci. Monaco, no. 83, p. 1-152.

Canu, F., 1906. Les Bryozoaires fossiles des terrains du SudOuest de la France: Soc. Géol. France Bull., ser. 4, v. 5, p. 515.

1907. Les Bryozoaires fossiles des terrains du SudOuest de la France. I. Aquitanien: Soc. Géol. France Bull., ser. 4 , v. 6 , p. $510-518$.

, 1908. Les Bryozoaires des terrains tertiaires des environs de Paris: Ann. Paléontol., v. 3, p. 61-104.

, 1910. Les Bryozoaires fossiles des terrains du Sud-Ouest de la France. V. Lutétien et VI. Bartonien: Soc. Géol. France Bull., ser. 4, v. 10, p. 840-855.

1914. Les Bryozoaires fossiles des terrains du SudOuest de la France. VII. Lutétian: Soc. Géol. France Bull., ser. 4 , v. 13 , p. $298-303$. 
1918. Les Bryozoaires fossiles des terrains du SudOuest de la France. XI. Rupelian (= Stampien): Soc. Géol. France Bull., ser. 4, v. 17, p. 350-361.

1925. Les Bryozoaires du lutétien de SaintGermain-en-Laye: Soc. Sci. Seine-et-Oise Bull., v. 6, p. 4648.

1931. Bryozoaires de Saint-Palais. In Abrard, R., Etude stratigraphique et paléontologique des calcaires de Saint-Palais et de Blaye: Soc. Géol. France Bull., ser. 5, v. 1, p. 3-22.

Canu, F. and Bassler, R.S., 1917. A synopsis of American early Tertiary cheilostome Bryozoa: U.S. Nat. Mus. Bull., v. 96, p. 1-87.

1920. North American early Tertiary Bryozoa: U.S. Nat. Mus. Bull., v. 106, p. 1-879.

1929. Bryozoaires éocènes de la Belgique conservés au Musée royal d'Histoire naturelle de Belgique: Mus. Roy. Hist. Nat. Belgique Mém., no. 39, p. 1-69.

1933. The bryozoan fauna of the Vincentown limesand: U.S. Nat. Mus. Bull., v. 165, p. 1-108.

Cheetham, A.H., 1963. Late Eocene zoogeography of the eastern Gulf Coast region: Geol. Soc. Am. Mem. 91, p. 1113.

1966. Cheilostomatous Polyzoa from the Upper Bracklesham Beds (Eocene) of Sussex: British Mus. (Nat. Hist.), Geol., Bull., v. 13, p. 1-115.

1968. Evolution of zooecial asymmetry and origin of poricellariid Cheilostomes. In Annoscia, E. (Ed.), Proc. 1st Internat. Conf. Bryozoa: Atti Soc. Italiana Sci. Nat., v. 108 , p. $185-194$.

1973. Study of cheilostome polymorphism using principal components analysis. In Larwood, G.P. (Ed.), Living and fossil Bryozoa: Recent advances in research: London (Academic Press), p. 385-409.

Cheetham, A.H. and Hakansson, E., 1972. Preliminary report on Bryozoa (Site 117). In Laughton, A.S., Berggren, W.A., et al., Initial Reports of the Deep Sea Drilling Project, Volume 12: Washington (U.S. Government Printing Office), p. 432-441.

Dartevelle, E., 1933. Contribution à l'Etude des Bryozoaires fossiles de l'Eocène de la Belgique: Soc. Roy. Zool. Belgique Ann., v. 63 , p. $55-166$.

1935. Bryozoaires du lutétien de Gomerfontaine: Soc. Roy. Zool. Belgique Ann., v. 65, p. 111-126.

Ducasse, O., Klingebiel, A., Labracherie, M., Prud'homme, J., Puechmaille, C., and Veillon, M., 1963. Contribution à l'analyse sédimentologique et paléontologique de la coupe de la citadelle de Blaye (Gironde): Procès-verbaux Soc. Linn. Bordeaux, v. 100, p. 130-140.

Ducasse, O. and Labracherie, M., 1967a. Etude paléontologique et stratigraphique des quelques affleurements du Medoc: Inst. Géol. Bassin d'Aquitaine Bull., v. 3, p. 21-28. 1967b. Observations paléontologiques sur la coupe profonde de Ludon (Gironde): Inst. Géol. Bassin d'Aquitaine Bull., v. 3, p. 35-58.

Ducasse, O., Labracherie, M., and Vigneaux, M., 1961. La Paléoécologie des Bryozoaires et Ostracodes fossiles dans l'interprétation biostratigraphique de l'Eocène moyen et supérieur au nord de Bordeaux: Procès-verbaux Soc. Linn. Bordeaux, v. 98, p. 1-16.

Gorodiski, A. and Balavoine, P., 1962. Bryozoaires Crétacés et Eocènes du Sénégal: Bu. Rech. Géol. Min. Bull., v. 4, p. 116.

Harmelin, J.G., 1970. Les Cribrilaria (Bryozoaires Chilostomes) de Méditerranée; systematique et écologie: Cah. Biol. Mar., v. 11, p. 77-98.

Harmer, S.F., 1926. The Polyzoa of the Siboga Expedition, part 2, Cheilostomata Anasca: Siboga Exped. Repts. Leyden, v. 28b, p. 181-501.
1957. The Polyzoa of the Siboga Expedition, part 4, Cheilostomata Ascophora II: Siboga Exped. Rept., Leyden, v. 28d, p. 641-1147.

Koschinsky, C., 1885. Ein Beitrag zur Kenntniss der Bryozoenfauna der älteren Tertiärschichten des südlichen Bayerns, I. Cheilostomata: Palaeontographica, v. 32, p. 173.

Labracherie, M., 1968. Quelques Bryozoaires Cheilostomes de la Falaise de Handia (Biarritz, France). In Annoscia, E. (Ed.), Proc. 1st Internatl. Conf. Bryozoa: Atti Soc. Italiana Sci. Naturali, v. 108 , p. 312-326.

1970. Nouveaux Bryozoaires de la famille des Farciminariidae du Tertiaire aquitain: Soc. Géol. France Bull., ser. 7, v. 11, p. 630-637.

1971. Evolution générale des assemblages de Bryozoaires dans l'Eocène du bassin nord-aquitaine: Compte Rendu Soc. Géol. France, v. 21, p. 388-389.

1973. Functional morphology and habitat of Bryozoa in the Eocene of the northern Aquitaine basin, France. In Larwood, G.P. (Ed.), Living and fossil Bryozoa: Recent advances in research: London (Academic Press), p. 129-138.

Labracherie, M. and Prud'homme, J., 1967. Observations paléoécologiques sur les Bryozoaires des formations classiques de Blayais: Actes Soc. Linn. Bordeaux, v. 104, p. 3-9.

Lagaaij, R., 1968. First fossil finds of six genera of Bryozoa Cheilostomata. In Annoscia, E. (Ed.), Proc. 1st Internatl. Conf. Bryozoa: Atti Soc. Italiana Sci. Naturali, v. 108, p. 345-360.

Lagaaij, R. and Cook, P.L., 1973. Some Tertiary to Recent Bryozoa. In Hallam, A. (Ed.), Atlas of Paleobiogeography: Amsterdam (Elsevier Scientific Publishing Co.), p. 489-498.

Malecki, J., 1963. Bryozoa from the Eocene of the Central Carpathians between Grýbow and Dukla: Polska Akad. Nauk, Prace Geologiczne, v. 16, p. 1-158.

Milne Edwards, H., 1836. Observations sur les Polypiers fossiles du genre Eschare: Ann. Sci. Nat. (Zool.), Paris, v. 6, p. 321-345.

d'Orbigny, A., 1850. Prodrome de Paleontologie Stratigraphique Universelle...: Paris (Masson), v. 2, p. 1427.

Paghida, N., 1961. Briozoarele din Tortonianul din nord-estul Moldovei: Anal. Stiint. Univ. "Al. I. Cusa”, (Stiinte naturale), v. 7, p. 383-396.

Pazdro, Z., 1929. Mszywioly z Lupków Menilitowych w Skalniku i ich Znaczenie Stratygraficzne: "Kosmos" czasopisma Polskiego Towarzystwa Przyrodników im Kopernika, v. 54 , p. $140-170$.

Reuss, A.E., 1848. Die fossilen Polyparien des Wiener Tertiärbeckens: Haidingers Naturwiss. Abhandl., Wien, no. 2, p. 1-109.

1869. Paläontologische Studien uber die älteren Tertiärschichten der Alpen, II Abtheilung. Die fossilen Anthozoen und Bryozoen der Schichtengruppe von Crosara: Kais. Academie der Wissenschaften Denkschriften math.-naturwiss. Classe, v. 30, p. 215-298.

Ruiz de Gaona, M. and Colom, G., 1950. Estudios sobre las sinecias de las Foraminiferos Eocénicos de la Vertiente Meridional del Pirineo (Cataluña-Vizcaya): Estud. Geol. Inst. "Lucas Mallada," v. 6, p. 293-434.

Soule, D.F. and Soule, J.D., 1973. Morphology and speciation of Hawaiian and eastern Pacific Smittinidae (Bryozoa, Ectoprocta): Am. Mus. Nat. Hist. Bull., v. 152, p. 365-440.

Stach, L.W., 1935. Victorian Tertiary Catenicellidae (Bryozoa), part III: Roy. Soc. Victoria Proc., v. 48, p. 2749.

Waters, A.W., 1891. North Italian Bryozoa, part I. Cheilostomata: Geol. Soc. London Quart. J., v. 47, p. 1-34. 


\section{PLATE 1}

All specimens approximately $\times 50$, unless indicated otherwise; from Site 308, early Eocene.

Figures 1-3 Scrupariid? gen. and sp. indet., Sample 308-3, CC.

1. Frontal view, $\times 60$; USNM 210841 .

2. Left lateral view, $\times 60$; USNM 210842.

3. Basal view, $\times 60$; USNM 210843.

Figure 4

Antropora? sp., Sample 308-3, CC; USNM 210844.

Figures 5, $6 \quad$ Nellia aff. $N$. ventricosa (Canu), Sample 308-3, CC.

5 . Broken specimen, showing ovicell; USNM 210845.

6. Poorly preserved specimen with ovicell; USNM 210846.

Figures 7, $8 \quad$ Poricellaria cf. P. limanowskii (Canu), Sample 3083, CC; USNM 210847.

7. Frontal view.

8. Right frontal view, $\times 60$, showing elongate opesiule.

Figures 9, 10 Epistomiid? gen. and sp. indet., Sample 308-3, CC.

9. Frontal view, $\times 60$; USNM 210848.

10. Basal view, $\times 60$; USNM 210849.

Figures 11, 12 Cribrilaria radiata (Moll), sensu lato, Sample 3083, CC.

11. Specimen with avicularium, USNM 210850.

12. Zooecium with eight oral spines, USNM 210851 .

Figures 13-17 Vittaticellid? n. gen. n. sp., Sample 308-3, CC.

13. Monozooecial internode, frontal view, $\times 60$; USNM 210852.

14. Monozooecial internode, left lateral view, $\times 60$; USNM 210853.

15. Monozooecial internode, basal view, $\times 60$; USNM 210854.

16. Dizooecial internode, basal view, $\times 60$; USNM 210855.

17. Biserial, polyzooecial? internode, $\times 60$; USNM 210856.

Figures 18-22 Smittinid n. gen. ? n. sp., Sample 308-2, CC.

18. Frontal view, showing morphology of orifice and partly developed avicularium near growing tip of colony; USNM 210857.

19. Frontal view, showing ovicelled and nonovicelled zooecia; USNM 210858.

20. Basal view, showing encrusting attachment of colony; USNM 210859.

21. Basal view, showing sector lines and pores; USNM 210860.

22. Frontal view, showing nonovicelled zooecia with and without avicularia; USNM 210861. 
PLATE 1

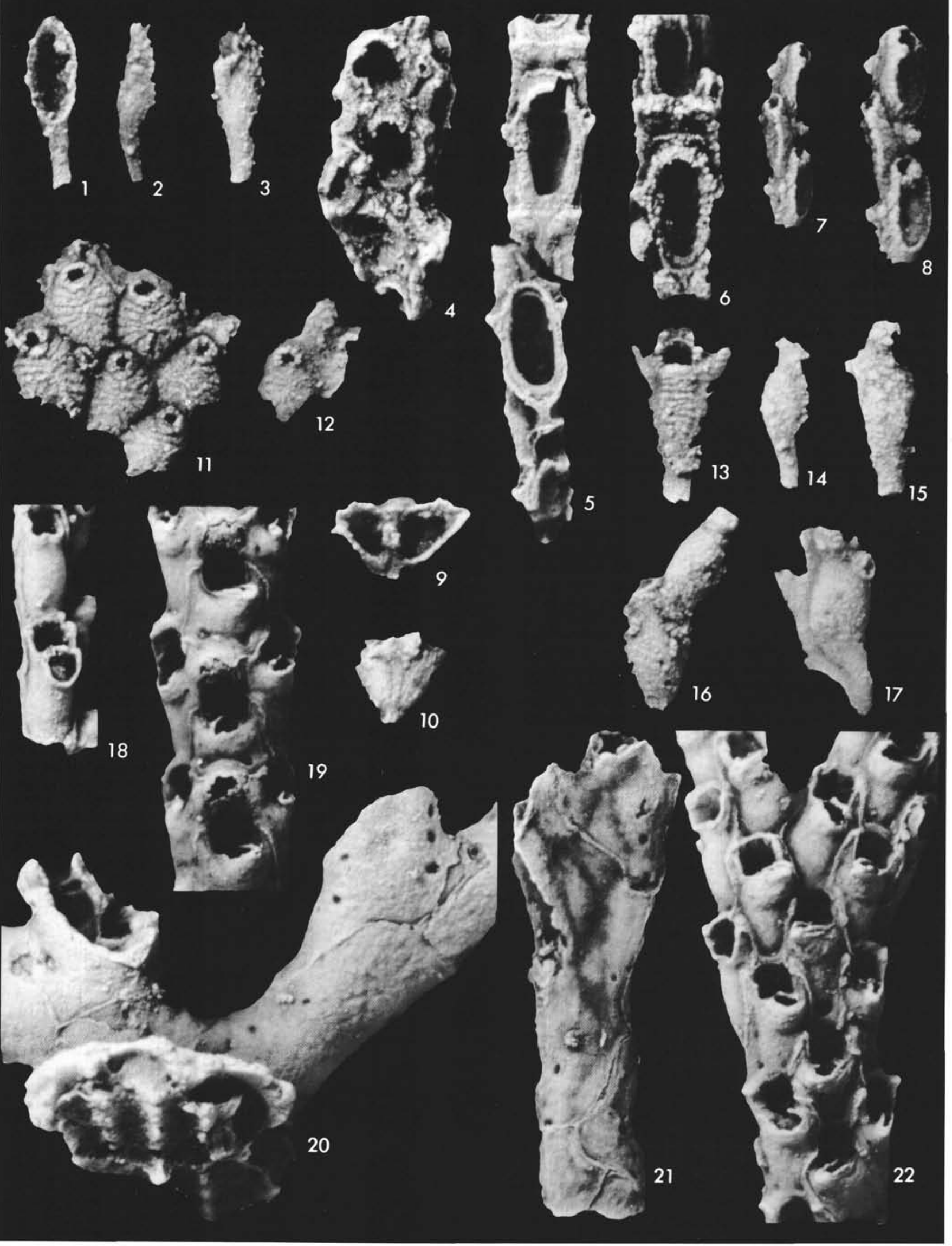




\section{PLATE 2}

All specimens approximately $\times 50$, from Site 308 , early Eocene.

Figures 1-6 Tubucella n. sp. 1.

1. Zooecia with slightly lateral suboral avicularia; USNM 210862; Sample 308-1, CC.

2. Zooecia showing ontogenetic changes from distal, growing margin; USNM 210863; Sample 308$2, \mathrm{CC}$.

3. Zooecia some of which have secondary orifices closed; USNM 210864; Sample 308-1, CC.

4. Zooecia with median to slightly lateral suboral avicularia; USNM 210865; Sample 308-1, CC.

5. Subcylindrical zoarial fragment, showing some zooecia with closed secondary orifices and some with additional avicularia; USNM 210866; Sample 308-1, CC.

6. Zooecia with avicularia having reversed orientation; USNM 210867; Sample 308-2, CC. 

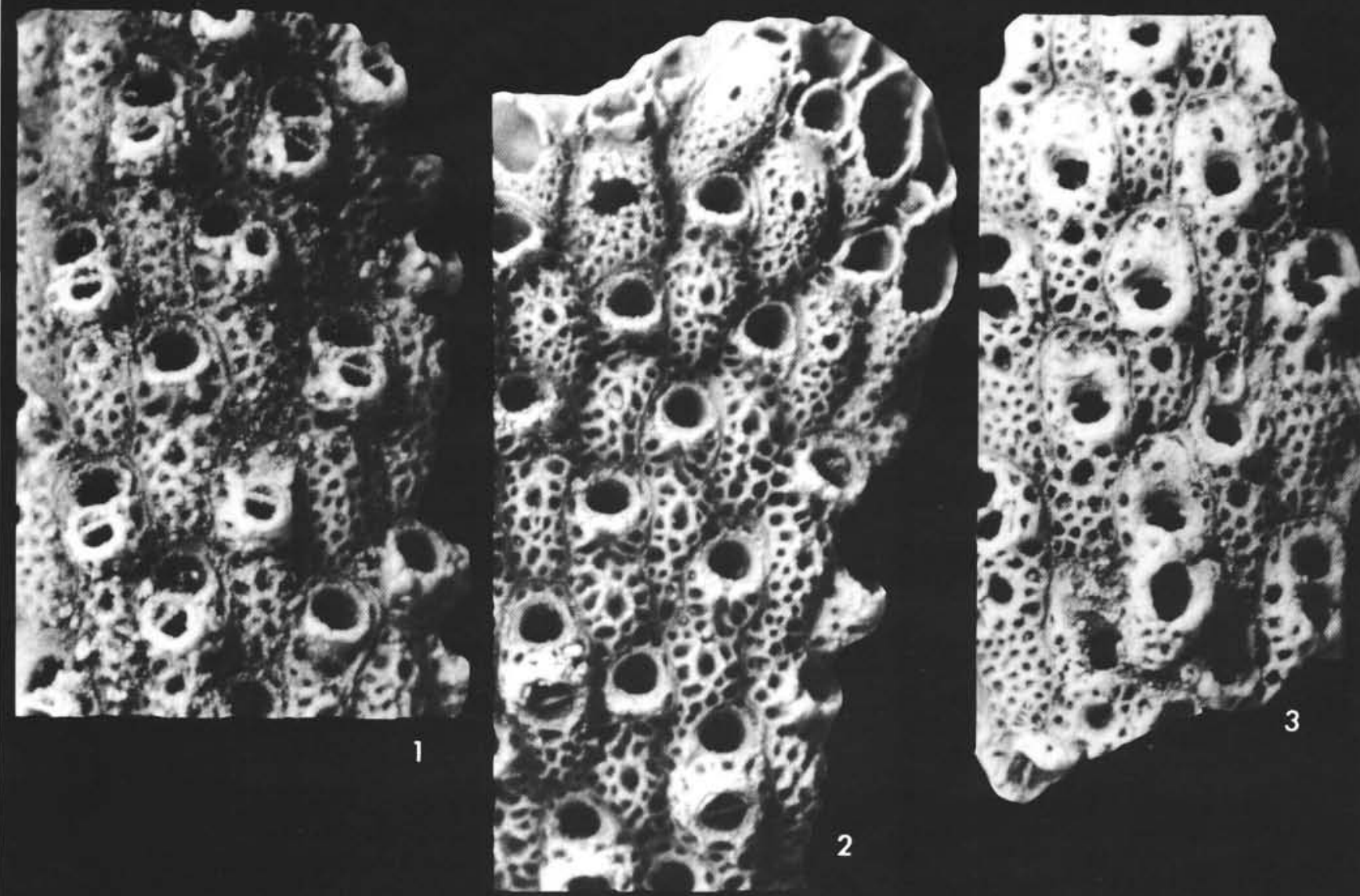

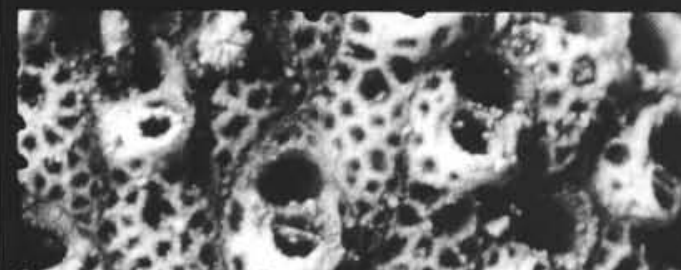

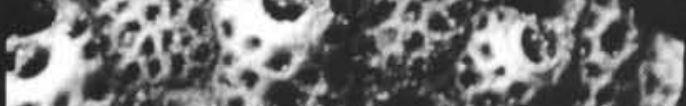

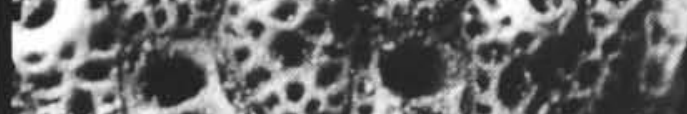

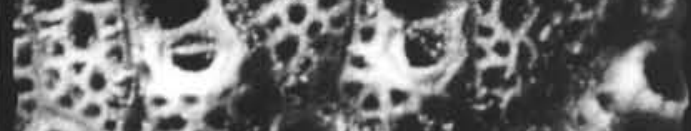

F.0.3.

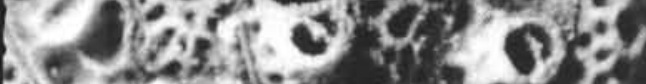

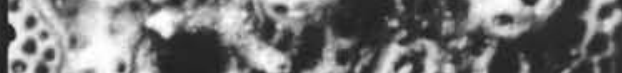

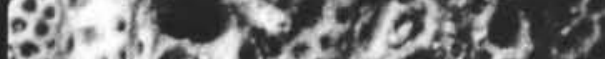

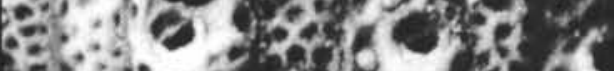
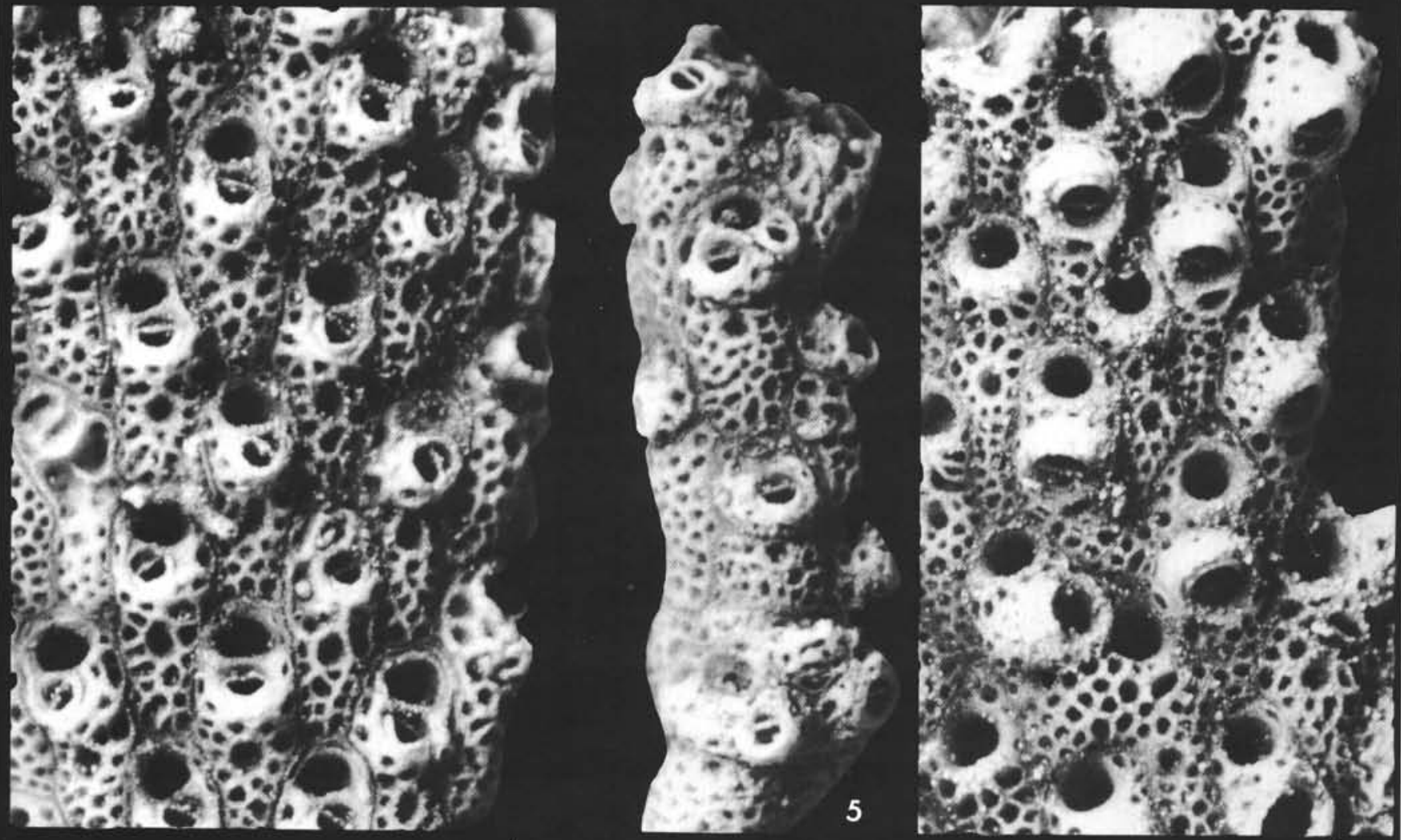


\section{PLATE 3}

All specimens approximately $\times 50$, from Site 308 , early Eocene.

Figures 1,2 Tubucella n. sp. 2, Sample 308-1, CC.

1. Ovicelled zooecia in central rows, nonovicelled zooecia in marginal rows; USNM 210871.

2. Nonovicelled zooecia with paired, single, or no avicularia, presumably from near growing edge of colony; USNM 210872.

Figures 3-5 Tubucella n. sp. 1, Sample 308-1, CC.

3. Zooecia with partially developed peristomes and prominently rimmed ascopores presumably close to growing margin of colony; USNM 210868 .

4. Ovicelled zooecia with distolateral avicularia in central rows; nonovicelled zooecia in marginal rows and at distal ends of central rows; USNM 210869 .

5. Ovicelled and nonovicelled zooecia both of which lack distolateral avicularia; USNM 210870. 


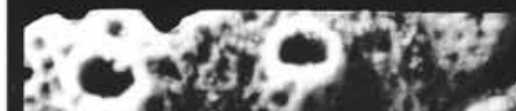

incol of 3

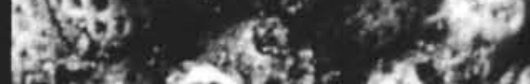

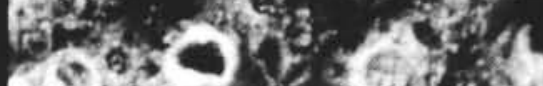

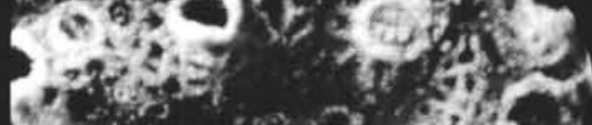

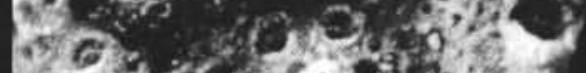

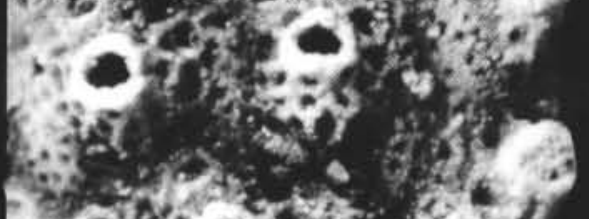

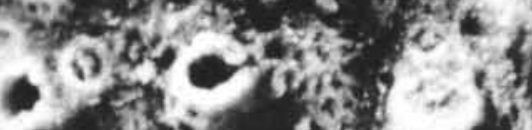

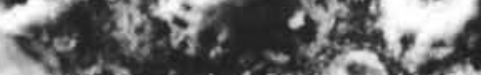

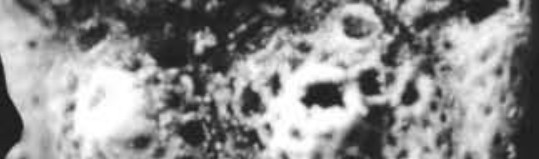

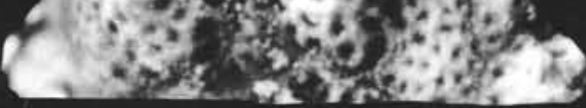

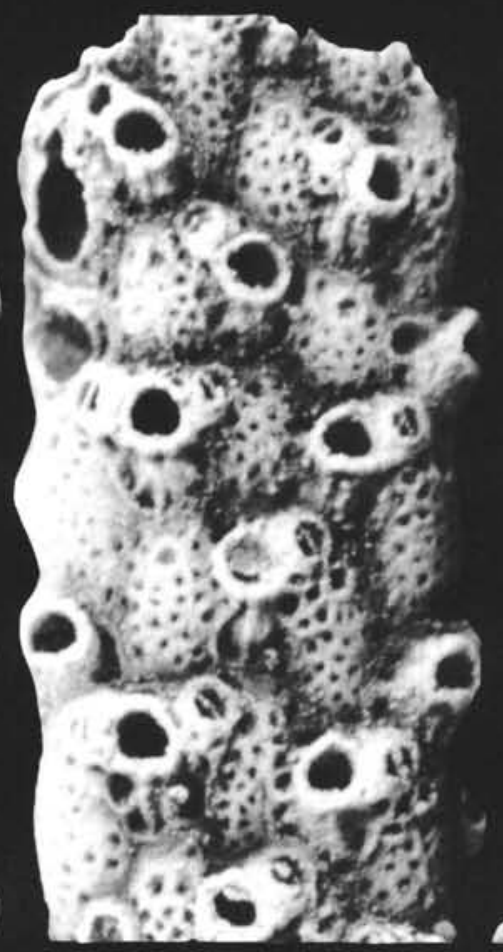

2

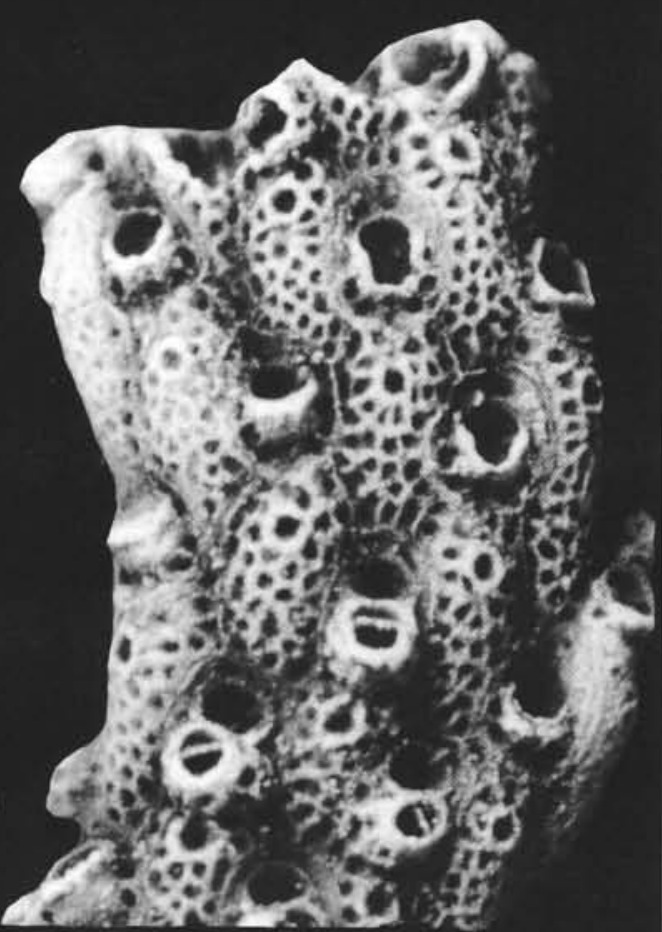

3

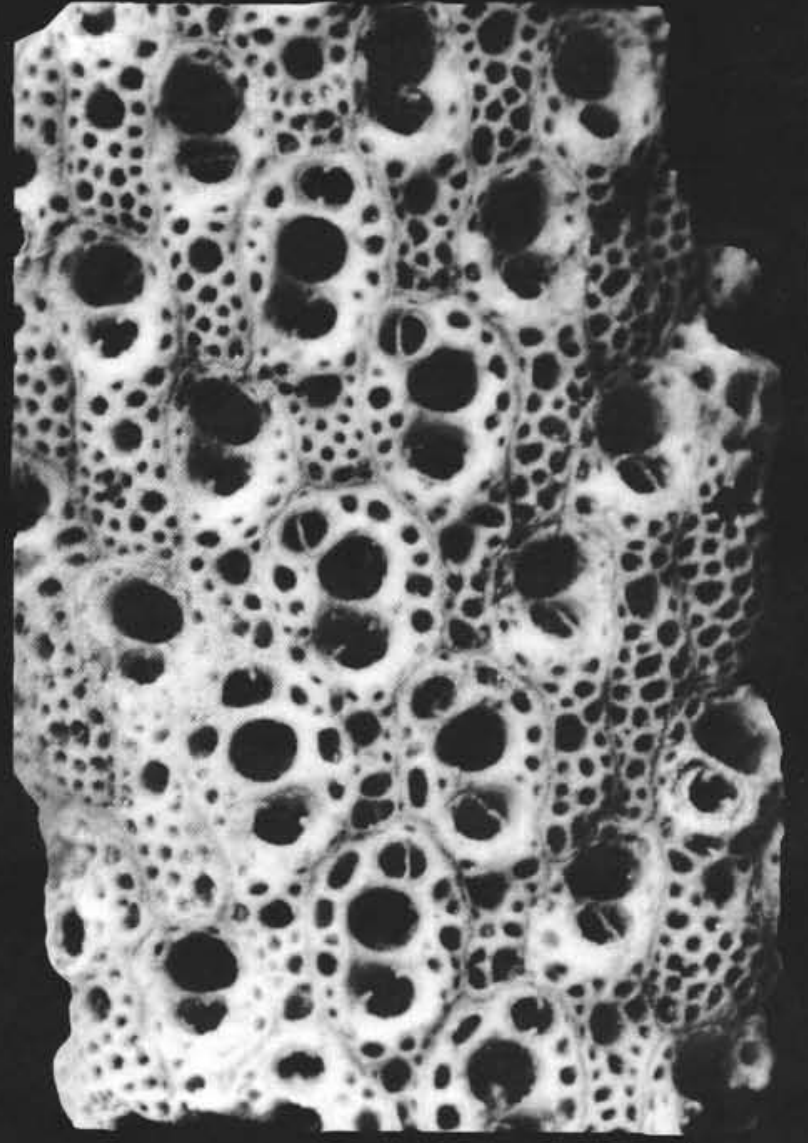

4

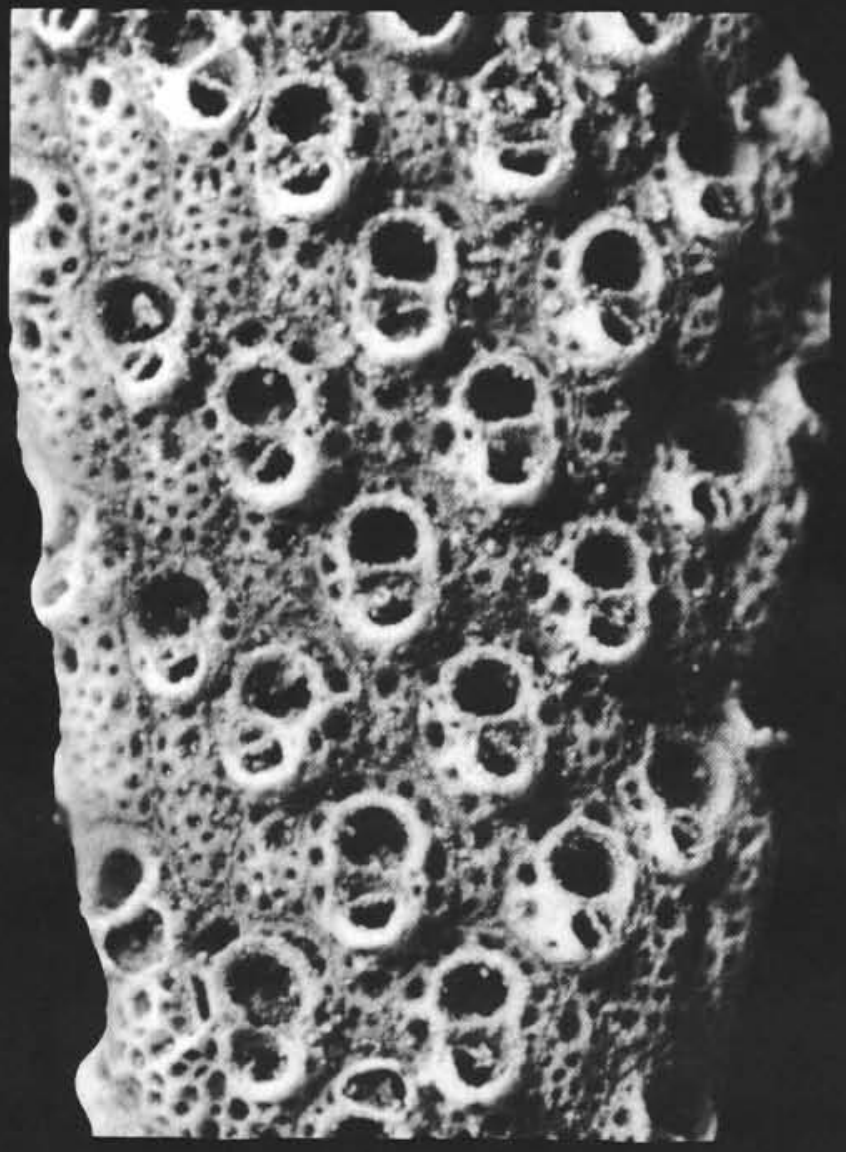




\section{PLATE 4}

All specimens approximately $\times 50$, from Site 308 , early Eocene.

Figures 1-5 Tubucella n. sp. 2.

1. Zooecia with secondary orifices closed by calcareous lamina and with presumed cuticular lines no longer following zooecial boundaries; USNM 210873; Sample 308-1, CC.

2. Subcylindrical zoarial fragment showing closed secondary orifices; USNM 210874; Sample 308-1, CC.

3. Zooecia with open secondary orifices, presumed cuticular lines not following zooecial boundaries; USNM 210875; Sample 308-1, CC.

4. Zooecia with disrupted presumed cuticular lines, closed secondary orifices, and some avicularia occluded; USNM 210876; Sample 3081, CC.

5. Zooecia for the most part with "normal" boundaries, secondary orifices, and avicularia; USNM 210877; Sample 308-3, CC. 
PLATE 4
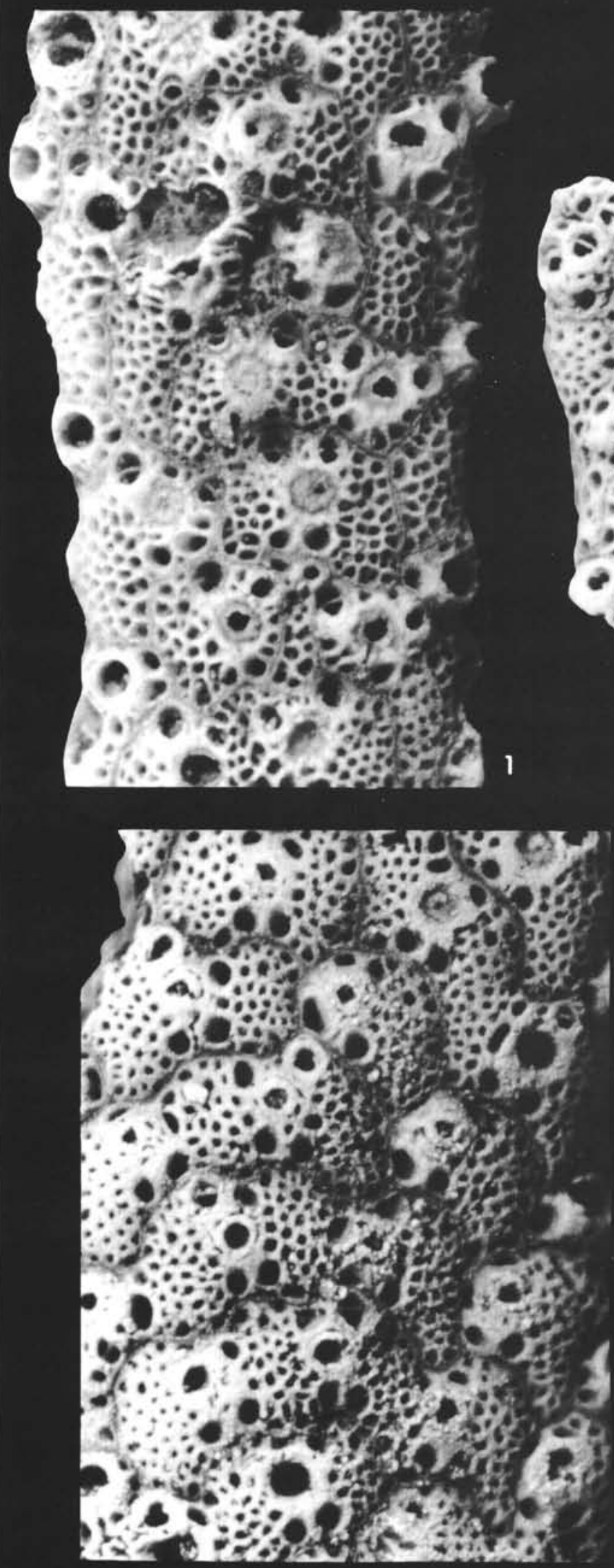

4

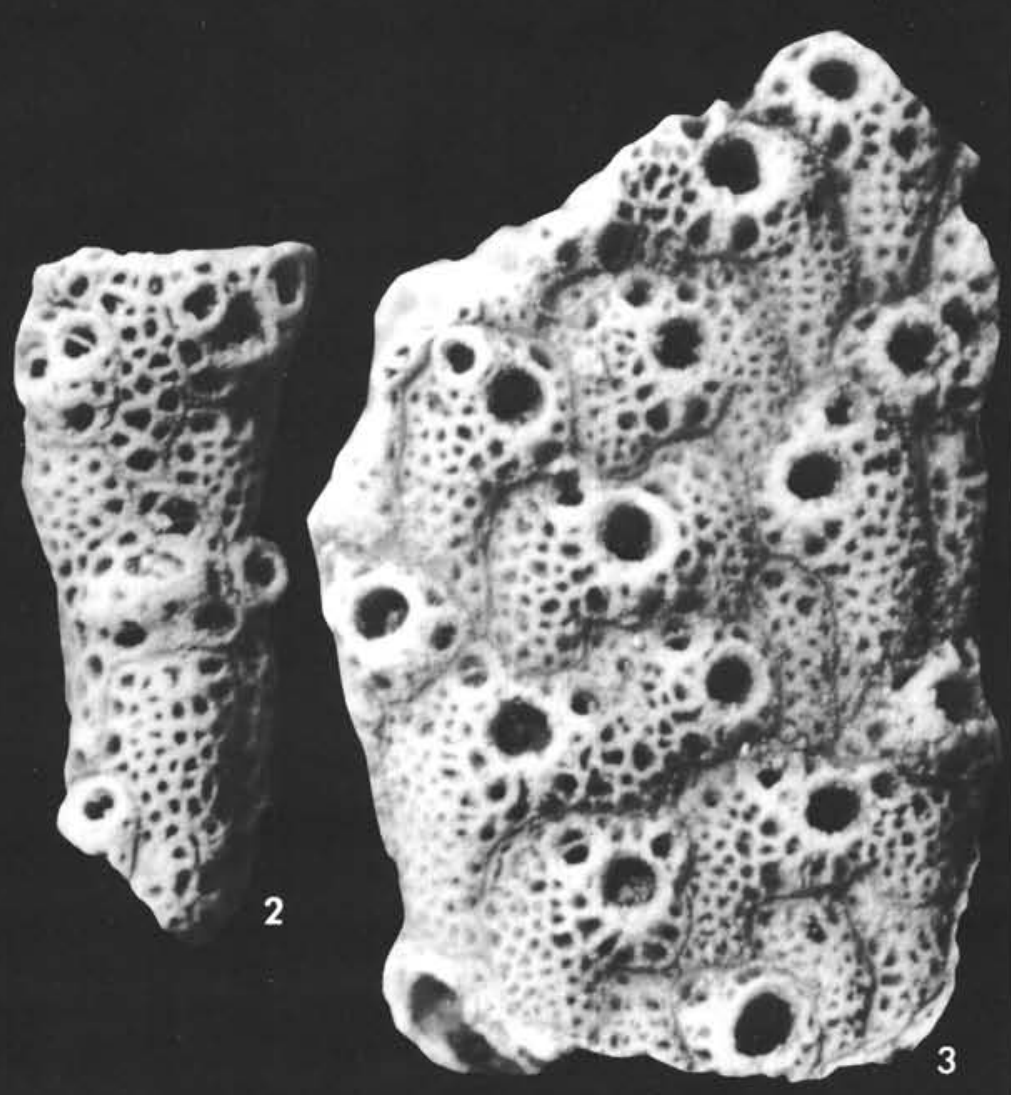

For

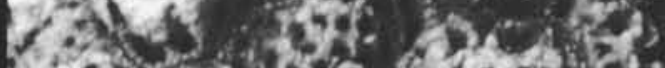

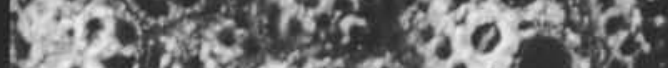

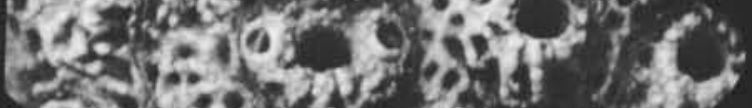

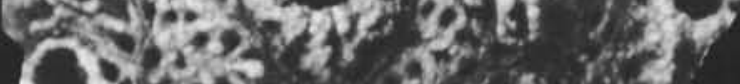

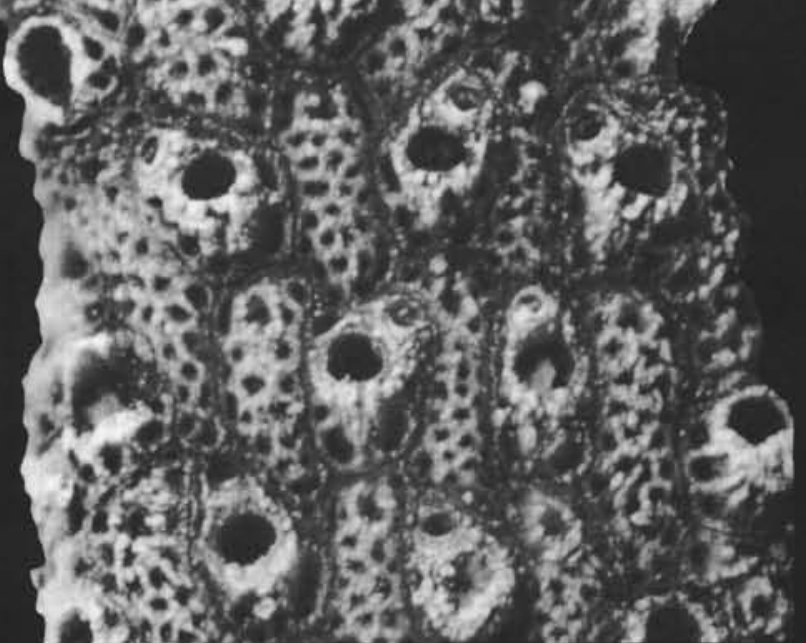

